\title{
Effect of transitional photoperiods on testicular development and puberty in male deer mice (Peromyscus maniculatus)
}

\author{
J. M. Whitsett, Patricia F. Noden*, J. Cherry and A. D. Lawton $\dagger$ \\ Department of Zoology, North Carolina State University, Raleigh, NC 27650, and \\ * Department of Anatomy, Physiological Sciences, and Radiology, School of Veterinary Medicine, \\ North Carolina State University, Raleigh, NC 27606, U.S.A.
}

\begin{abstract}
Summary. In a series of five experiments, young male deer mice (Peromyscus maniculatus bairdii) were exposed to photoperiods ranging in length from 3 to $19 \mathrm{~h}$ per 24-h period, as well as to constant light and constant darkness. Reproductive organ growth as measured at 6 weeks of age was inhibited by $\leq 11.5 \mathrm{~h}$ of light. In males receiving $11 \cdot 5-19 \mathrm{~h}$ of light, there was a quantitative increase in reproductive organ size as a function of photoperiod. Rather than a 'critical' photoperiod partitioning reproductive inhibition and stimulation, there was a zone of gradual transition from inhibition to full stimulation. Histological analysis of testes demonstrated that spermatogenesis was stimulated by long photoperiods. Examination of the epidermal surface of the penis by scanning electron microscopy indicated that penile spine development was also regulated by photoperiod.
\end{abstract}

\section{Introduction}

Photoperiod exerts a regulatory influence on pubertal development in several species of mammals (Foster, 1981 ; Grocock, 1981 ; Hoffmann, 1981; Tahka, Ruokonen, Wallgren \& Teravainen, 1983). Several investigations have demonstrated that long photoperiods accelerate and short photoperiods retard puberty in two species of cricetid mice of the genus Peromyscus (Johnston \& Zucker, 1980; Petterborg \& Reiter, 1980; Whitsett \& Miller, 1982).

It is sufficient in most investigations of photoperiodism to use one photoperiod that is unequivocally stimulatory and another that is unequivocally inhibitory. The transition from an inhibitory to a stimulatory photoperiod has been examined in only a few species of mammals (Elliott, 1976; Imel \& Amann, 1979; Lynch \& Gendler, 1980; Grocock, 1981; Hoffmann, 1981). Data on this transition are important for any intensive analysis of a photoperiodic phenomenon and are essential for an examination of the functional role of the circadian clock in pubertal development, a major goal of our research programme (Whitsett, Underwood \& Cherry, 1983; Whitsett, Cherry \& Underwood, 1984a). Such information might prove particularly interesting in prairie deer mice (Peromyscus maniculatus) because the range of this species includes a large portion of the North American continent (Hooper, 1968). The present report summarizes a series of experiments in which we compared the influence of 11 different lighting regimens on pubertal development in male prairie deer mice.

\section{General Methods}

Prairie deer mice (Peromyscus maniculatus bairdii) used in this study were born in the laboratory from a stock obtained from Dr John A. King at Michigan State University. The founders of the

$†$ Present address: Research Triangle Institute, Research Triangle Park, NC 27709, U.S.A. 
stock were trapped near East Lansing, Michigan (J. A. King, personal communication; Savidge, 1974). Deer mice were housed in $28.5 \times 18.5 \times 12.0 \mathrm{~cm}$ polypropylene cages on a bedding of shredded aspen, and were provided with tap water and Wayne F-6 Blox or Wayne Breeder Blox (during pregnancy and lactation) ad libitum. Females previously exposed to a photoperiod of $15 \mathrm{~h}$ light :9 dark (15L:9D) were bred by introducing a male into the home cage of a female and leaving him for 5-9 days.

In Exps 1, 2 and 3, the mated females remained in 15L :9D throughout pregnancy. Treatment of the offspring began on the day of birth or on the following day when mother-litter units were assigned on a random basis to one of 10 photoperiod chambers (described in Whitsett \& Lawton, 1982; Whitsett et al., 1983). Each chamber held 9 cages of mothers with litters; a given photoperiod treatment was imposed upon 2 chambers, i.e. 18 cages. A $30-\mathrm{W}$ fluorescent bulb in each chamber produced an average light intensity of 1100 lux at the level of the animals. Juvenile males were weaned at 21-22 days of age, housed individually, and maintained in the photoperiod of the preweaning period.

Puberty in male deer mice is readily accelerated by a change from a short to a long photoperiod at weaning (Whitsett, Lawton \& Miller, 1984b). We took advantage of this phenomenon to improve the efficiency of Exps 4 and 5 by assigning treatments to individuals rather than to mother-litter units. Prospective mothers were exposed to $6 \mathrm{~L}: 18 \mathrm{D}$ at the time of mating and continued in this lighting regimen through pregnancy and lactation. When weaned at 3 weeks of age, male offspring were housed individually and randomly assigned to a photoperiod treatment.

Males were killed by cervical dislocation at 6 weeks of age; bodies were frozen for later measurement of body weight and testis and seminal vesicle weights. Either a single testis was weighed or both were weighed and an average value for one was calculated. Additional measures for individual experiments are described below.

Statistical significance of treatment differences was determined by $F$ tests calculated using the General Linear Models procedure of the Statistical Analysis System (SAS Institute, Inc., 1982). Multiple comparisons were based on the Waller-Duncan K-ratio $t$-test $(\alpha=0.05$, SAS Institute, Inc., 1982).

\section{Detailed Methods and Results}

\section{Experiment 1}

Methods. Having in mind the great latitudinal range of prairie deer mice, we conducted Exp. 1 for the primary purpose of examining the response of pubertal development to a wide range of photoperiods. The second purpose of the experiment was to investigate the internal structure of the testis under conditions in which considerable inter-individual variation was anticipated. The final goal of Exp. 1 was to examine the usefulness of a measure of microscopic papillae or 'spines' on the penis as an index of reproductive maturity.

Mothers and litters were assigned at birth to a light/dark cycle of $3 \mathrm{~L}: 21 \mathrm{D}, 7 \mathrm{~L}: 17 \mathrm{D}$, $11 \mathrm{~L}: 13 \mathrm{D}, 15 \mathrm{~L}: 9 \mathrm{D}$ or $19 \mathrm{~L}: 5 \mathrm{D}$. Males were killed at 42 days of age. The left testis was removed and prepared for histological analysis as described below. An individual was then frozen at $-20^{\circ} \mathrm{C}$ for later necropsy, at which time the penis was removed, rinsed in $0.15 \mathrm{M}$-sodium cacodylate, fixed in $3 \%$ glutaraldehyde in $0.2 \mathrm{M}$-sodium cacodylate, and prepared for scanning electron microscopy as described by Whitsett, Ayer \& Muse (1980). The surface of the penis was examined and micrographs were prepared at a magnification of $\times 200$. We also measured body weight, area of the androgen-dependent sebaceous gland (Lawton \& Whitsett, 1979), and weights of seminal vesicles (containing secretions) and the right testis.

Histological preparation of the left testis proceeded as follows: the testis was fixed in Bouin's solution and stored in $70 \%$ ethanol to await processing. Each testis was embedded in paraffin wax and a $5-\mu \mathrm{m}$ cross-section was made through the centre of the testis. The tissue was stained with 
Harris' haematoxylin and eosin and sections were examined using a Leitz orthoplan and an eyepiece micrometer. Length and width of a cross-section were measured and area of the section was calculated using the formula for an ellipse. In one cross-section per animal, all tubules were evaluated for presence of spermatogonia, spermatocytes and spermatids. In 10 circular sections of tubules, each from a different region of the testis and each homogeneous throughout with respect to cell associations and spermiogenesis, we measured inner and outer diameters, calculated areas of the cellular and luminal regions of the tubule, and counted the number of 'late' spermatids present. This designation was applied to a cell that had an elongated nucleus, similar to Steps 11-16 of spermiogenesis in house mice (Oakberg, 1956) or that appeared to be a mature spermatozoon still attached to the luminal edge of the epithelium. Late spermatids were observed in tubules resembling cycle Stages I-VIII and XI-XII in mice (Oakberg, 1956; Clermont \& Trott, 1969).

A testis was rated for its spermatogenic potential (spermatogenic index) on a scale of 1 to 6 . The index was based on the appearance of the spermatogenic cells throughout the testis and included number of cell layers, types of cells, and the presence of late spermatids in the seminiferous tubules. The index and criteria were as follows: 1, only spermatogonia present; 2 , spermatogonia and spermatocytes present; 3 , spermatogonia, spermatocytes and round (early) spermatids present with $<5$ late spermatids per tubule; 4, spermatogonia, spermatocytes, and round spermatids present; and up to 25 late spermatids per tubule; 5 , all cell types present and 50-75 late spermatids per tubule; 6 , all cell types present and $\geq 100$ late spermatids per tubule.

Results. Body weight and reproductive organ size at 6 weeks of age were strongly influenced by photoperiod (Table 1). Multiple comparisons by the Duncan-Waller test indicated that deer mice subjected to 15 or $19 \mathrm{~h}$ light per $24 \mathrm{~h}$ were significantly heavier and had larger testes, seminal vesicles, and ventral sebaceous glands than did those receiving 3,7 or $11 \mathrm{~h} \mathrm{light}$. Average values for all measures were greater in the 19-h photoperiod group than in the 15-h group, but these differences were not statistically significant.

Deer mice receiving $\geq 15 \mathrm{~h}$ light per day had a higher density of epidermal spines on the penis than did those receiving $\leq 11 \mathrm{~h}$ light (Table 2) (Pl. 1, Figs $1 \& 2$ ).

The change from inhibition to stimulation of testicular microstructure also occurred between photoperiods of 11 and $15 \mathrm{~h}$ (Table 3). Both the cellular and luminal areas of the seminiferous tubules were greater in 15- and 19-h photoperiods than in photoperiods of $\leq 11 \mathrm{~h}$. Similarly, various measures of spermatogenic activity, including number of spermatids per tubule, spermatogenic index, and presence of spermatozoa in the epididymis, were stimulated by $15-$ and 19-h photoperiods. Plate 2 illustrates the extremes in the range of testicular development. The tubular crosssections of the well-developed testis (P1. 2, Fig. 3) represent 3 or more stages (Leblond \& Clermont,

Table 1. Influence of photoperiod on reproductive organ size and body weight in male deer mice at 6 weeks of age in Exp. 1

\begin{tabular}{|c|c|c|c|c|c|c|c|}
\hline & \multicolumn{5}{|c|}{ Photoperiod (hours) } & \multirow[b]{2}{*}{$\mathrm{F}(4,70)$} & \multirow[b]{2}{*}{$P<$} \\
\hline & 3 & 7 & 11 & 15 & 19 & & \\
\hline Body weight (g) & $\begin{array}{r}13 \cdot 9 \\
\pm 0 \cdot 3\end{array}$ & $\begin{array}{r}14.1 \\
\pm 0.7\end{array}$ & $\begin{array}{r}13.8 \\
\pm 0.4\end{array}$ & $\begin{array}{l}16 \cdot 1^{*} \\
\pm 0.5\end{array}$ & $\begin{array}{l}16.5^{*} \\
\pm 0.4\end{array}$ & $8 \cdot 17$ & 0.0001 \\
\hline Testis weight (mg) & $\begin{array}{r}46 \cdot 4 \\
\pm 7 \cdot 5\end{array}$ & $\begin{array}{r}38.5 \\
+8.5\end{array}$ & $\begin{array}{r}40.8 \\
\pm 6.9\end{array}$ & $\begin{array}{l}92 \cdot 8^{*} \\
\pm 7 \cdot 1\end{array}$ & $\begin{array}{l}105 \cdot 5^{*} \\
\pm 7 \cdot 1\end{array}$ & $18 \cdot 62$ & $0 \cdot 0001$ \\
\hline $\begin{array}{l}\text { Log seminal } \\
\text { vesicle weight (mg) }\end{array}$ & $\begin{array}{r}0.55 \\
\pm 0.10\end{array}$ & $\begin{array}{r}0.41 \\
\pm 0.13\end{array}$ & $\begin{array}{r}0.48 \\
+0.11\end{array}$ & $\begin{array}{l}1.51^{*} \\
\pm 0.09\end{array}$ & $\begin{array}{r}1.64^{*} \\
\pm 0.08\end{array}$ & $34 \cdot 63$ & 0.0001 \\
\hline $\begin{array}{l}\text { Sebaceous gland } \\
\text { area }\left(\mathrm{mm}^{2}\right)\end{array}$ & $\begin{array}{r}17 \cdot 3 \\
\pm 4 \cdot 0\end{array}$ & $\begin{array}{r}18.5 \\
\pm 6.5\end{array}$ & $\begin{array}{r}21 \cdot 0 \\
\pm 6 \cdot 1\end{array}$ & $\begin{array}{l}39 \cdot 8^{*} \\
\pm 3.6\end{array}$ & $\begin{array}{l}49.4^{*} \\
\pm 4.9\end{array}$ & $8 \cdot 56$ & $0 \cdot 0001$ \\
\hline Sample size & 16 & 15 & 13 & 13 & 18 & & \\
\hline
\end{tabular}

Values are mean \pm s.e.m.

* Significantly different from means for 3,7 and 11 -h groups $(\alpha=0 \cdot 05)$. 
Table 2. Influence of photoperiod on development of papillae on proximal or distal glans penis of male deer mice at 6 weeks of age in Exp. 1

\begin{tabular}{|c|c|c|c|c|c|c|}
\hline \multirow[b]{2}{*}{ Site } & \multirow[b]{2}{*}{ Measure* } & \multicolumn{5}{|c|}{ Photoperiod (hours) } \\
\hline & & 3 & 7 & 11 & 15 & 19 \\
\hline Distal & $\begin{array}{l}\% \text { with papillae } \\
\text { Median density } \\
\text { Mean } \pm \text { s.e.m. density }\end{array}$ & $\begin{array}{c}38 \\
0 \\
13 \cdot 0 \pm 7 \cdot 3\end{array}$ & $\begin{array}{c}38 \\
0 \\
22 \cdot 5 \pm 14 \cdot 0\end{array}$ & $\begin{array}{c}25 \\
0 \\
11 \cdot 6 \pm 7 \cdot 6\end{array}$ & $\begin{array}{c}88 \\
36 \\
43 \cdot 0 \pm 11 \cdot 2\end{array}$ & $\begin{array}{c}100 \\
45 \\
43 \cdot 4 \pm 4 \cdot 5\end{array}$ \\
\hline Proximal & $\begin{array}{l}\% \text { with papillae } \\
\text { Median density } \\
\text { Mean } \pm \text { s.e.m. density } \\
\text { Sample size }\end{array}$ & $\begin{array}{c}25 \\
0 \\
8 \cdot 9 \pm 5 \cdot 8 \\
\frac{8}{8}\end{array}$ & $\begin{array}{c}25 \\
0 \\
12 \cdot 6 \pm 9 \cdot 0 \\
8\end{array}$ & $\begin{array}{c}38 \\
0 \\
10 \cdot 8 \pm \frac{6}{8}\end{array}$ & $\begin{array}{c}88 \\
29 \\
30 \cdot 6 \pm 6 \cdot 4 \\
8\end{array}$ & $\begin{array}{c}100 \\
27 \\
26 \cdot 8 \pm 1 \cdot 3 \\
9\end{array}$ \\
\hline
\end{tabular}

* Density $=$ no. of papillae $/ 0.25 \mathrm{~mm}^{2}$.

Table 3. Effects of photoperiod on testicular function in deer mice at 6 weeks of age in Exp. 1

\begin{tabular}{|c|c|c|c|c|c|c|c|}
\hline \multirow[b]{2}{*}{ Measure } & \multicolumn{5}{|c|}{ Photoperiod (hours) } & \multirow[b]{2}{*}{$F(4,68)$} & \multirow[b]{2}{*}{$P<$} \\
\hline & 3 & 7 & 11 & 15 & 19 & & \\
\hline \multicolumn{8}{|l|}{ Cross-sectional area of: } \\
\hline Testis $\left(\mathrm{mm}^{2}\right)$ & $\begin{array}{r}24.7 \\
+2.6\end{array}$ & $\begin{array}{r}24.4 \\
+3.8\end{array}$ & $\begin{array}{r}24.8 \\
+2.7\end{array}$ & $\begin{array}{c}40.6^{*} \\
+2.4\end{array}$ & $\begin{array}{c}44.4^{*} \\
+1.8\end{array}$ & $13 \cdot 12$ & $0 \cdot 0001$ \\
\hline \multirow[t]{2}{*}{ Seminiferous tubule $\times 10^{3}\left(\mu \mathrm{m}^{2}\right)$} & $11 \cdot 3$ & $8 \cdot 3$ & 10.0 & $15 \cdot 6^{*}$ & $16 \cdot 5^{*}$ & $10 \cdot 25$ & 0.0001 \\
\hline & \pm 1.4 & $\pm 1 \cdot 0$ & $\pm 1 \cdot 1$ & $\pm 0 \cdot 7$ & $\pm 1 \cdot 0$ & & \\
\hline Tubule lumen $\times 10^{3}\left(\mu \mathrm{m}^{2}\right)$ & $\begin{array}{r}1.0 \\
+0.2\end{array}$ & $\begin{array}{r}0.9 \\
+0.2\end{array}$ & $\begin{array}{r}1.0 \\
+0.2\end{array}$ & $\begin{array}{r}1.8^{*} \\
+0.2\end{array}$ & $\begin{array}{r}2.1^{*} \\
+0.2\end{array}$ & 7.65 & $0 \cdot 0001$ \\
\hline \multirow{2}{*}{$\begin{array}{l}\text { Cellular portion of tubule } \\
\times 10^{3}\left(\mu \mathrm{m}^{2}\right)\end{array}$} & $10 \cdot 3$ & 7.4 & 9.0 & $13.8 *$ & $14 \cdot 4^{*}$ & 10.06 & 0.0001 \\
\hline & $\pm 1 \cdot 3$ & \pm 0.9 & $\pm 1 \cdot 0$ & \pm 0.7 & \pm 0.8 & & \\
\hline \multirow[t]{2}{*}{ Spermatids/tubule (no.) } & $38 \cdot 6$ & $23 \cdot 1$ & 32.7 & $75 \cdot 6^{*}$ & $83 \cdot 8^{*}$ & $12 \cdot 25$ & 0.0001 \\
\hline & $\pm 9 \cdot 2$ & $\pm 6 \cdot 5$ & $\pm 8 \cdot 3$ & $\pm 6 \cdot 0$ & \pm 7.9 & & \\
\hline \multirow[t]{2}{*}{ Spermatogenic index } & 4.5 & $4 \cdot 0$ & $4 \cdot 3$ & $5 \cdot 3^{*}$ & $5 \cdot 4^{*}$ & $11 \cdot 39$ & 0.0001 \\
\hline & $\pm 0 \cdot 2$ & \pm 0.2 & $\pm 0 \cdot 2$ & $\pm 0 \cdot 1$ & $\pm 0 \cdot 1$ & & \\
\hline $\begin{array}{l}\text { Animals with epididymal } \\
\text { spermatozoa }(\%)\end{array}$ & $31 \cdot 3$ & $33 \cdot 3$ & 53.8 & $100 \cdot 0^{*}$ & $100 \cdot 0^{*}$ & $\chi^{2}=31.6$ & 0.0001 \\
\hline Sample size & 16 & 15 & 13 & 13 & 16 & & \\
\hline
\end{tabular}

Values are mean \pm s.e.m.

* Significantly different from means or percentages (Fisher's exact test) for 3, 7 and 11-h groups $(\alpha=0.05)$.

1952) of the cycle of the seminiferous epithelium. More than 100 late spermatids are present at the luminal edge of the seminiferous tubule in Pl. 2, Fig. 4. The tubules in the undeveloped testis shown in PI. 2, Figs $5 \& 6$ appear to be devoid of spermatids in any stage of development.

The strength of the association between various measures of the internal structure of the testis was determined by the calculation of correlation coefficients. All measures illustrated in Table 3 were positively and strongly correlated (e.g. cellular area of seminiferous tubule and number of spermatids per tubule: $r=0.88$ ). These histological measures were also correlated with the

\section{PLATE 1}

Fig. 1. Scanning electron micrograph of surface of penis of a deer mouse exposed to an 11-h photoperiod from birth to 6 weeks of age in Exp. 1. $\times 190$.

Fig. 2. Micrograph of surface of penis of a male deer mouse exposed to a 15 -h photoperiod from birth to 6 weeks of age. $\times 190$. 

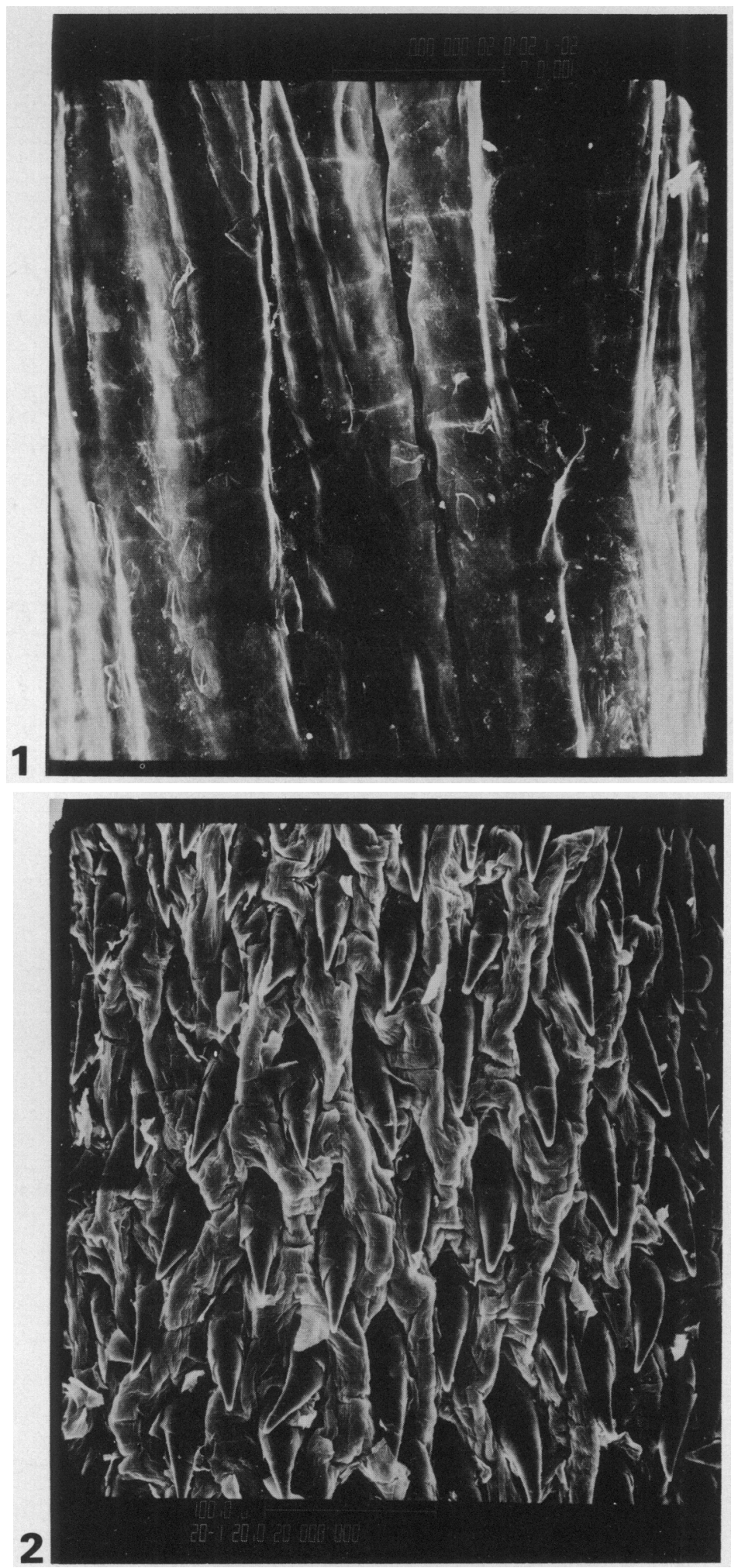
PLATE 2

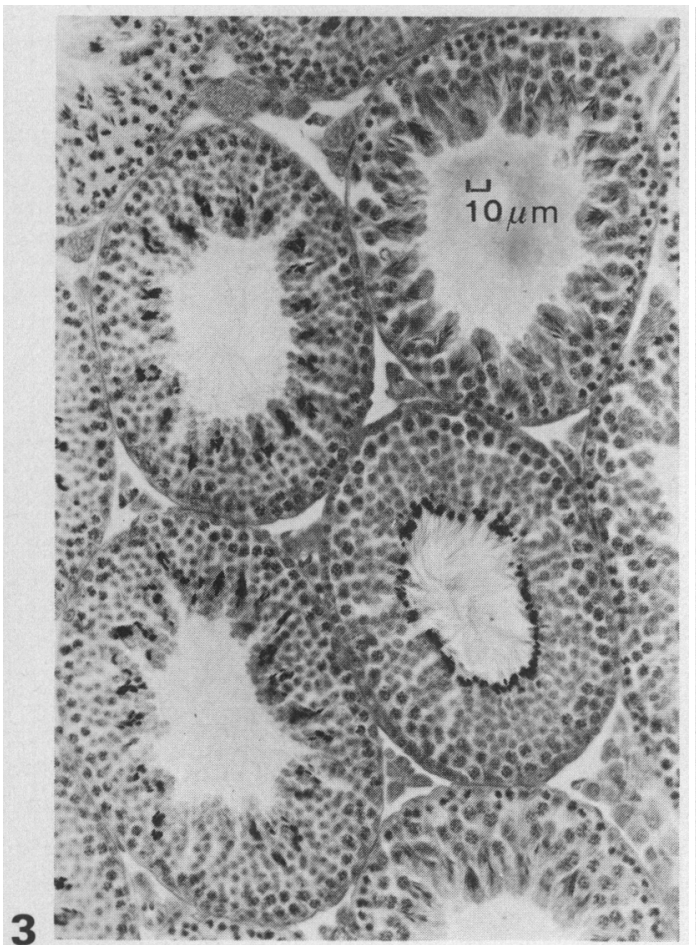

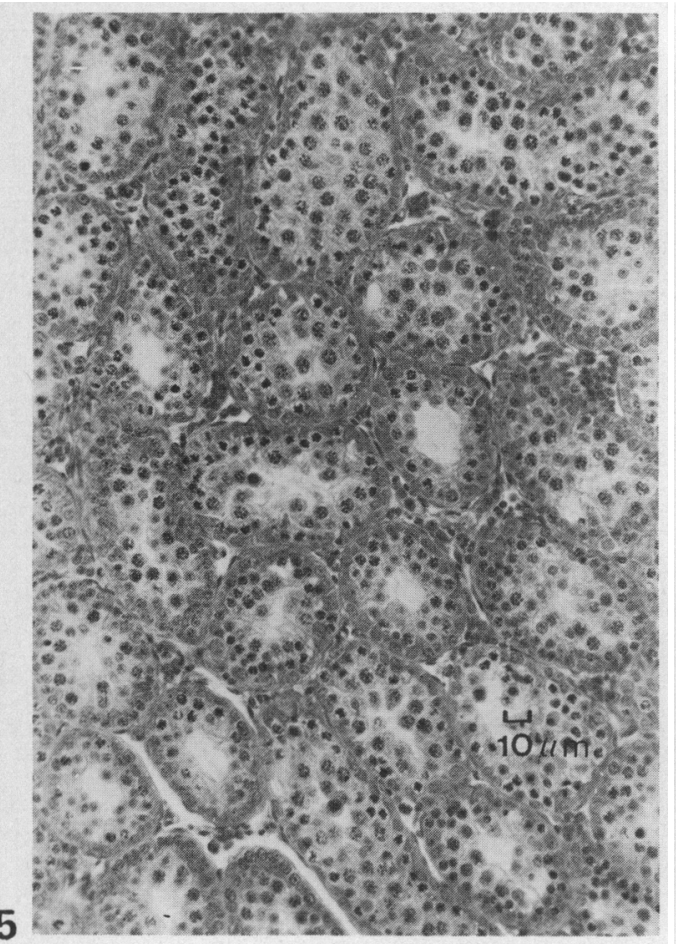

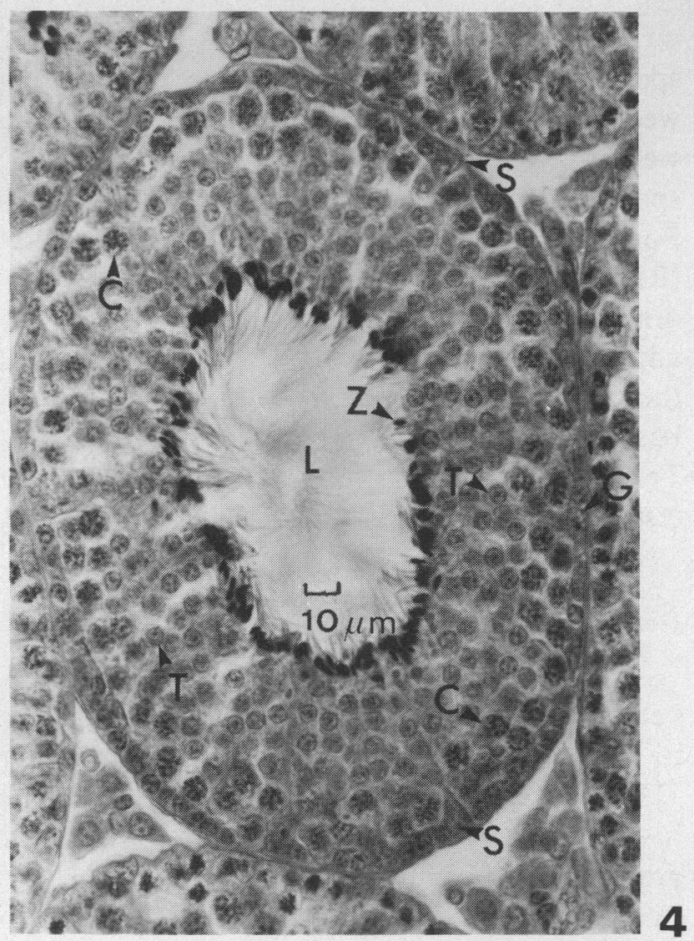

$4^{4}, \frac{5}{2}$.

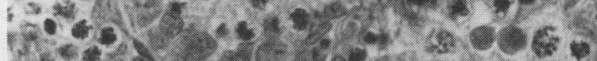

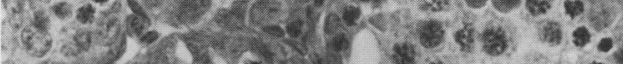

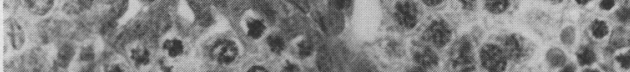

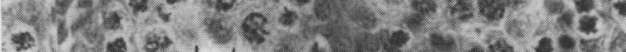

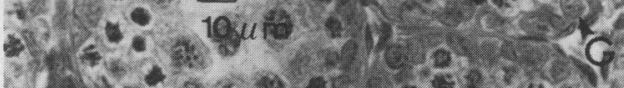

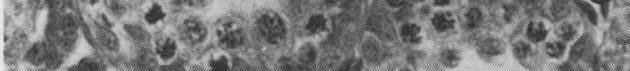

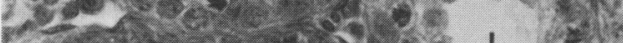

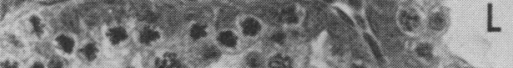

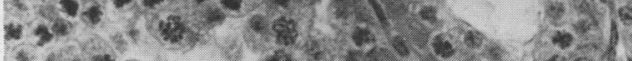

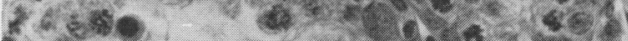
E.

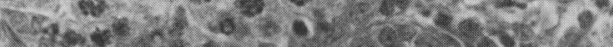

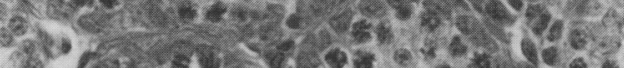

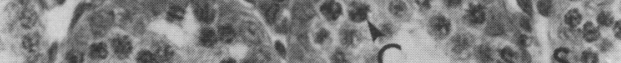

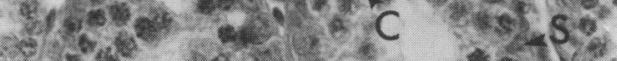

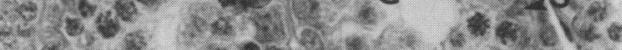

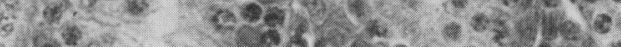

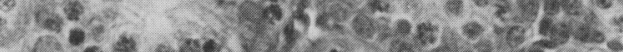

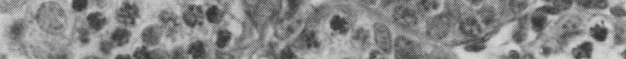

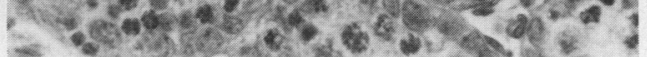


occurrence of spermatozoa in the epididymis, as determined immediately after death (e.g. spermatogenic index and epididymal spermatozoa: $r=0.79$ ). Finally, the internal characteristics were highly correlated with gross size of the testis (e.g. number of spermatids per tubule and testis weight: $r=0.87$ ). Text-figure 1 illustrates the structure of the association between abundance of spermatids and size of microscopic structures and between microstructure and macroscopic size. For preparation of Text-fig. 1(b), weight was judged to be a reasonable index of volume of the testis (Riggs, 1963, p. 34), and therefore this value was raised to the $1 / 3$ power to reduce the number of dimensions from 3 to 1 for comparison with diameter of seminiferous tubules. The result of this adjustment was a linearization of the relation between testis weight and tubule diameter. Following the same line of reasoning, we used the $2 / 3$ power of testis weight for comparison with the areabased histological measures. The strong linear association between the variables is apparent in Text-figs 1(a) and 1(b). Internal structure of the testis is a good predictor of sperm production, and testis weight is a good predictor of both internal structure and sperm production.

\section{Experiment 2}

The transition from an inhibitory to a stimulatory influence on pubertal development occurred between photoperiods of 11 and $15 \mathrm{~h}$ in Exp. 1, and this region of transition was examined in detail in Exp. 2. Rearing procedures were as described above, except that the photoperiods tested were 11L:13D, 12L:12D, 13L:11D, 14L:10D and 15L:9D. As in Exp. 1, males receiving $15 \mathrm{~h}$ of light had larger reproductive organs than did those in the 11-h group (Table 4). Males in the 13- and 14-h groups had intermediate values; males in $14 \mathrm{~L}: 10 \mathrm{D}$ had larger testes and seminal vesicles, and those in 13L:11D had larger testes, than did those in $11 \mathrm{~L}: 13 \mathrm{D}$. The occurrence of large reproductive organs in males kept in 12L:12D was anomalous in that organs in this group were substantially larger than those in the 11L:13D group and larger than most of those in males in the longer photoperiod groups.

\section{Experiment 3}

This and the next experiment were conducted to determine whether the high rate of reproductive growth in males in $12 \mathrm{~L}: 12 \mathrm{D}$ was a replicable phenomenon, as well as to provide additional information regarding photoperiods in the transitional zone. Males were exposed from birth to $11 \mathrm{~L}: 13 \mathrm{D}, 12 \mathrm{~L}: 12 \mathrm{D}, 13 \mathrm{~L}: 11 \mathrm{D}$ or $14 \mathrm{~L}: 10 \mathrm{D}$. In addition, one group was reared in $11 \cdot 5 \mathrm{~L}: 12 \cdot 5 \mathrm{D}$ to delineate further a 'critical' period, if $12 \mathrm{~L}: 12 \mathrm{D}$ again proved stimulatory. However, neither the 11.5- nor the 12-h photoperiod stimulated reproductive growth (Table 4).

\section{PLATE 2}

Fig. 3. Several seminiferous tubules from the well-developed testis of a deer mouse housed in a 19-h photoperiod from birth to 6 weeks of age in Exp. 1. Note late spermatids on the luminal edge of the seminiferous cellular area in the tubule on the lower right and dark-staining nuclei of younger spermatids in the other tubules. Spermatogonia and spermatocytes are present in all tubules. $\times 190$.

Fig. 4. Higher power view of the same testis as Fig. 3. Note spermatogonia (G), spermatocytes (C), Sertoli cells (S), early spermatids (T), and late spermatids (Z) near the lumen (L). This testis was assigned a spermatogenic index value of $6 . \times 375$.

Fig. 5. Several seminiferous tubules from the poorly-developed testis of a deer mouse kept in a 7-h photoperiod. $\times 190$.

Fig. 6. Higher power view of the same testis as Fig. 5. Spermatogonia and spermatocytes are present. Degenerating cells having eosinophilic cytoplasm and pycnotic nuclei (E) are visible. This testis was assigned a spermatogenic index value of $2 . \times 375$. 

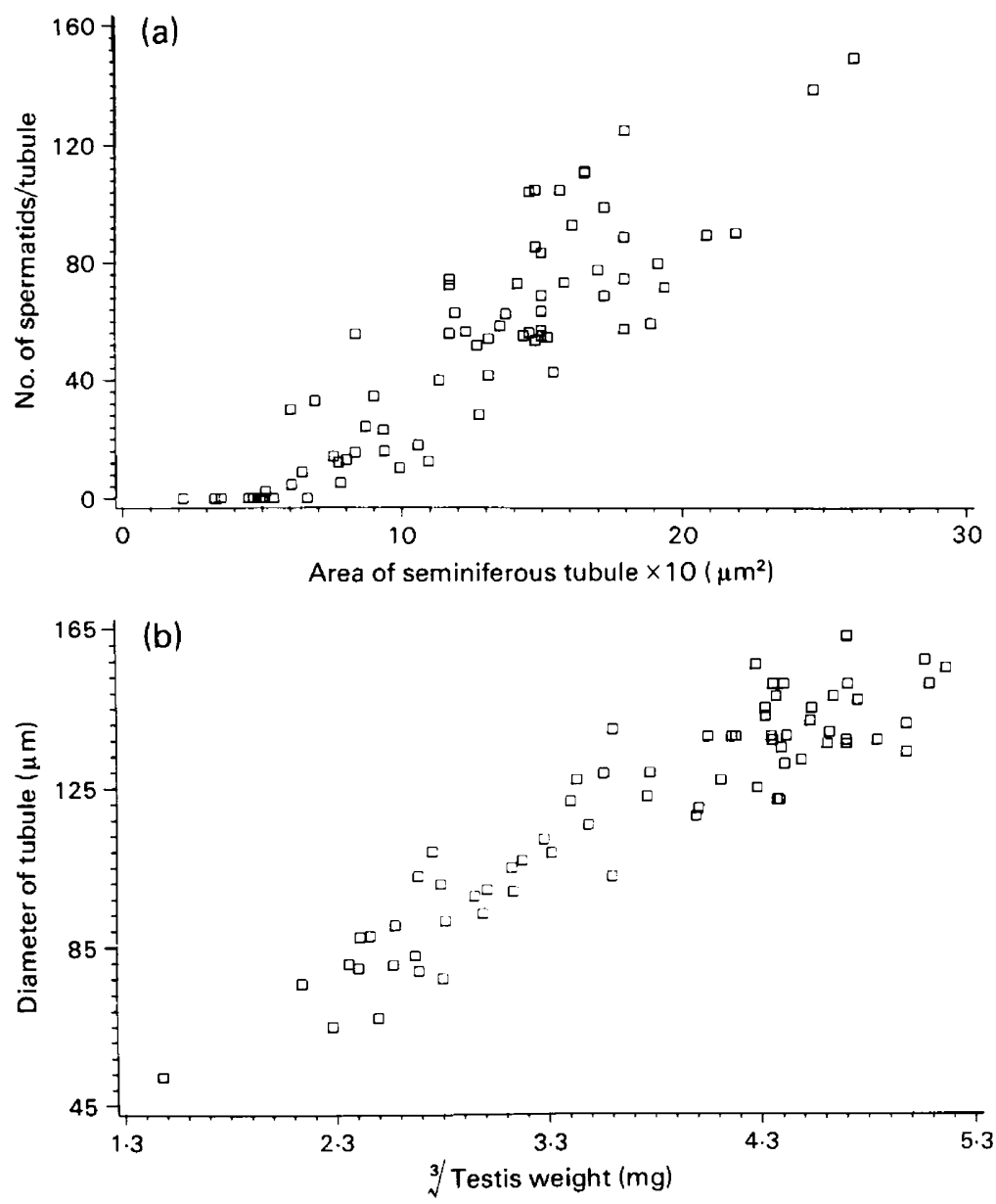

Text-fig. 1. Scatter diagrams relating (a) cross-sectional area of seminiferous tubule and number of spermatids per tubular section and (b) diameter of seminiferous tubule and testis weight (cube root) in male deer mice at 6 weeks of age in Exp. 1. Sample sizes $=73$ pairs of values. Correlation coefficients $=0.89$ in (a), 0.93 in (b).

\section{Experiment 4}

Males were reared from weaning in $11 \mathrm{~L}: 13 \mathrm{D}, 12 \mathrm{~L}: 12 \mathrm{D}$ or $15 \mathrm{~L}: 9 \mathrm{D}$. Males exposed to $15 \mathrm{~L}: 9 \mathrm{D}$ had larger reproductive organs than did those in $11 \mathrm{~L}: 13 \mathrm{D}$ males (testis weight: $74.5 \pm 4.8$ compared with $56.6 \pm 5.1 \mathrm{mg}$, respectively; $\log _{10}$ seminal vesicle weight measured in $\mathrm{mg}: 1.29 \pm 0.07$ compared with $0.82 \pm 0.11)$. Testes $(66.6 \pm 6.4 \mathrm{mg})$ and seminal vesicles $(0.87 \pm 1.0)$ of the males in $12 \mathrm{~L}: 12 \mathrm{D}$ were not significantly different from those of the males in $11 \mathrm{~L}: 13 \mathrm{D}$ (all comparisons: Duncan-Waller, $\alpha=0.05, n=24$ per treatment condition). Body weight was not influenced by photoperiod.

Experiments 3 and 4 failed to confirm the finding in Exp. 2 of a strong stimulatory influence of a 12-h photoperiod on pubertal development. Consequently, data from the suspect group were excluded from the composite frequency distributions in Text-fig. 3. We suspect that the original finding was a consequence of an undetected malfunction in equipment. The effectiveness of the other photoperiods was consistent from one experiment to another. 
Table 4. Influence of photoperiod on reproductive organ size and body weight in male deer mice killed at 6 weeks of age in Exps 2 and 3

\begin{tabular}{|c|c|c|c|c|c|c|c|c|c|}
\hline \multirow[b]{2}{*}{ Measure } & \multirow[b]{2}{*}{ Exp. } & \multicolumn{6}{|c|}{ Photoperiod (hours) } & \multirow[b]{2}{*}{$F(d f)$} & \multirow[b]{2}{*}{$P<$} \\
\hline & & 11 & $11 \cdot 5$ & 12 & 13 & 14 & 15 & & \\
\hline Body weight (g) & $\begin{array}{l}2 \\
3\end{array}$ & $\begin{array}{r}14.4 \\
\pm 0.4 \\
15.0 \\
\pm 0.4\end{array}$ & $\begin{array}{r}- \\
\overline{15 \cdot 2} \\
\pm 0 \cdot 4\end{array}$ & $\begin{array}{r}15.0 \\
\pm 0.4 \\
15.0 \\
\pm 0.4\end{array}$ & $\begin{array}{r}16.5 \\
\pm 0.5 \\
15.0 \\
\pm 0.4\end{array}$ & $\begin{array}{r}15.4 \\
\pm 0.4 \\
15.2 \\
\pm 0.3\end{array}$ & $\begin{array}{r}15.5 \\
\pm 0.4 \\
- \\
-\end{array}$ & $\begin{array}{c}3 \cdot 36 \\
(4,83) \\
1 \\
(4,85)\end{array}$ & $\begin{array}{r}0.02 \\
\text { NS }\end{array}$ \\
\hline Testis weight (mg) & $\begin{array}{l}2 \\
3\end{array}$ & $\begin{array}{r}41.6 \\
\pm 7.6 \\
45.5 \\
\pm 6.4\end{array}$ & $\begin{array}{r}- \\
51.7 \\
\pm 6.2\end{array}$ & $\begin{array}{r}90 \cdot 1 \\
\pm 6 \cdot 1 \\
49.6 \\
\pm 7.4\end{array}$ & $\begin{array}{r}72.5 \\
\pm 7 \cdot 3 \\
66.9 \\
\pm 7.0\end{array}$ & $\begin{array}{r}73.8 \\
\pm 5.0 \\
78.9 \\
\pm 5.0\end{array}$ & $\begin{array}{r}81 \cdot 8 \\
\pm 4 \cdot 1 \\
- \\
-\end{array}$ & $\begin{array}{c}6 \cdot 68 \\
(4,83) \\
4 \cdot 66 \\
(4,85)\end{array}$ & $\begin{array}{l}0.001 \\
0.005\end{array}$ \\
\hline $\begin{array}{l}\text { Log seminal } \\
\text { vesicle weight }(\mathrm{mg})\end{array}$ & $\begin{array}{l}2 \\
3\end{array}$ & $\begin{array}{r}0.67 \\
\pm 0.10 \\
0.42 \\
\pm 0.12\end{array}$ & $\begin{array}{r}- \\
- \\
0.64 \\
\pm 0.14\end{array}$ & $\begin{array}{r}1.29 \\
\pm 0.10 \\
0.63 \\
\pm 0.16\end{array}$ & $\begin{array}{r}1.05 \\
\pm 0.12 \\
0.92 \\
\pm 0.12\end{array}$ & $\begin{array}{r}1.13 \\
\pm 0.11 \\
1.31 \\
\pm 0.09\end{array}$ & $\begin{array}{r}1.46 \\
\pm 0.09 \\
- \\
-\end{array}$ & $\begin{array}{c}8 \cdot 59 \\
(4,83) \\
7 \cdot 19 \\
(4,85)\end{array}$ & $\begin{array}{l}0.0001 \\
0.0001\end{array}$ \\
\hline Sample size & $\begin{array}{l}2 \\
3\end{array}$ & $\begin{array}{l}17 \\
18\end{array}$ & $\frac{-}{18}$ & $\begin{array}{l}18 \\
18\end{array}$ & $\begin{array}{l}17 \\
18\end{array}$ & $\begin{array}{l}18 \\
18\end{array}$ & 18 & & \\
\hline
\end{tabular}

Values are mean \pm s.e.m.

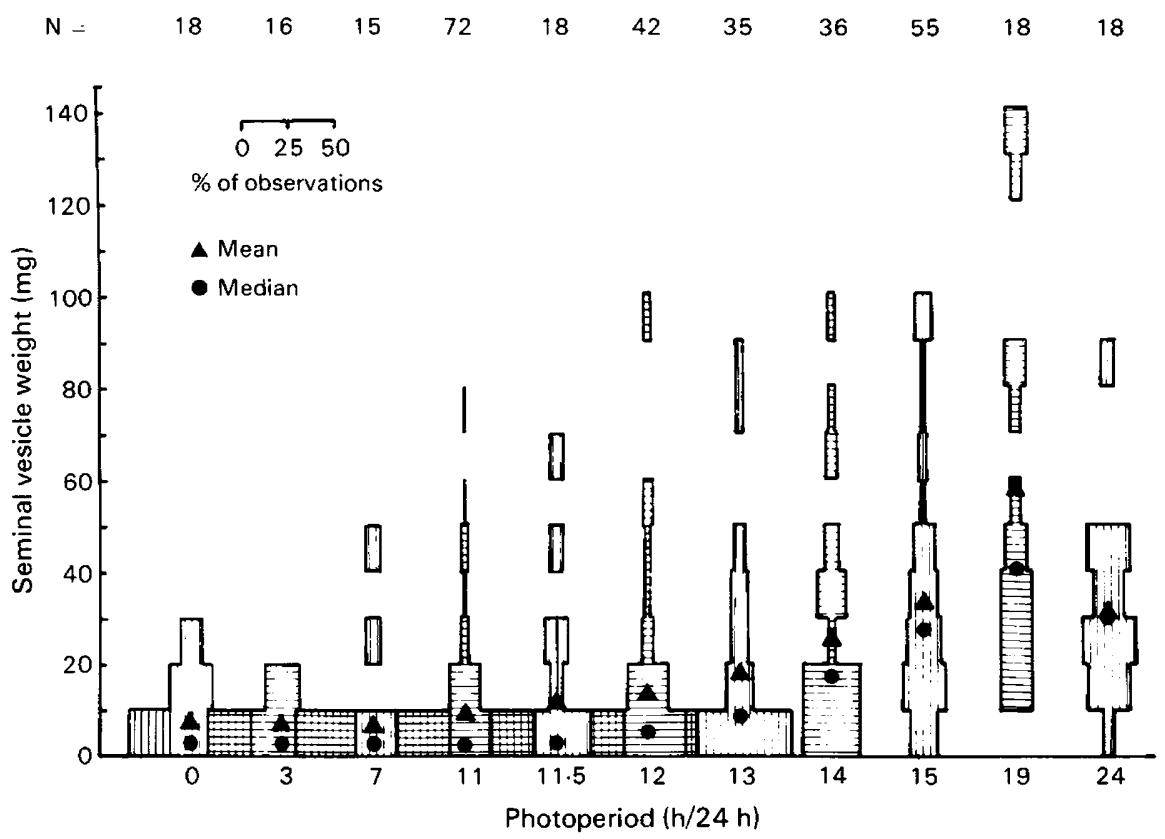

Text-fig. 2. Frequency distributions of weights of seminal vesicles in male deer mice at 6 weeks of age in Exps 1-5. Distributions are presented for each lighting regimen tested. Width of bar represents proportion of individuals falling within weight interval indicated on ordinate. Total sample size $=343$ individuals. 


\section{Experiment 5}

An essential datum in an attempt to understand the role of the circadian clock in the regulation of a physiological process is knowledge of the behaviour of the system in the absence of environmental periodicity. In photoperiodic adults stimulated by long days, exposure to constant darkness typically inhibits the reproductive system (Elliott, 1976); the influence of exposure to constant light on reproduction varies from one species and function to another (Hoffmann, 1973). The purpose of Exp. 5 was to examine the effects of constant photic conditions on pubertal development in male deer mice.

Males exposed to constant light from weaning to 6 weeks of age were heavier and had larger reproductive organs than did males exposed to constant darkness (sample size $=18$ per group; body weights: $17.4 \pm 0.5$ and $15.3 \pm 0.5 \mathrm{~g}$, respectively, $\mathrm{F}(1,34)=10.32, P<0.005$; testis weights: $82.4 \pm 6.5$ and $52.6 \pm 7.9 \mathrm{mg}, \mathrm{F}(1,34)=8.50, P<0.01 ; \log _{10}$ seminal vesicle weights in $\mathrm{mg}: 1.41 \pm 0.07$ and $0.66 \pm 0.09, \mathrm{~F}(1,34)=41 \cdot 13, P<0.0001)$.

\section{Discussion}

The pattern of pubertal response to all photoperiods tested in the study may be seen in Text-fig. 2 . Average seminal vesicle weights were quite low in all groups receiving $0-11.5 \mathrm{~h}$ light per $24 \mathrm{~h}$. Between 11.5 and $19 \mathrm{~h}$ light, average seminal vesicle weight increased as a function of photoperiod. The relation between photoperiod and seminal vesicle size is reasonably well characterized by the logistic growth curve. The finding of incremental pubertal development in response to increased photoperiod resembles data from adult white-footed mice (Lynch \& Gendler, 1980), juvenile voles (Grocock, 1981), and birds of several species including white-crowned sparrows (Farner \& Wilson, 1957), but is different from data for adult golden hamsters and developing Djungarian hamsters, in which there is an abrupt shift from reproductive inhibition to reproductive stimulation when photoperiod reaches the 'critical' length (Elliott, 1976; Hoffmann, 1981).

Deer mice are unusual as research animals in that high variability is endemic to the species; they are characterized by a proliferation of subspecies and races (Hooper, 1968), an "extraordinary" divergence in nucleotide sequence of mitochondrial DNA (Lansman, Avise, Aquadro, Shapira \& Daniel, 1983), a breeding season of variable length (Sullivan, 1979), a loosely organized circadian system (Pittendrigh \& Daan, 1976), and great variation in responsiveness to environmental stimuli. Desjardins \& Lopez (1983), for example, found that only about $25 \%$ of adult males underwent reproductive inhibition after exposure to a short photoperiod. Text-figure 2 illustrates the variability in pubertal development in deer mice reared in different photoperiods.

There are several possible explanations for the high variability in the reproductive development of deer mice. Desjardins \& Lopez (1983) have suggested the likelihood of genetic differences in responsiveness of reproductive function in adult deer mice to several environmental factors, including photoperiod; this genetically-based differential responsiveness might also be true of developing individuals. A recent demonstration of latitudinal differences in the role of photoperiod in testicular development (Dark, Johnston, Healy \& Zucker, 1983) is consistent with this view. Genetic variation in growth processes uninfluenced by photoperiod is another potential source of reproductive variation. A third possible explanation is that individual deer mice entrain differently to a given light/dark cycle and, because of the involvement of the circadian system in the photoperiodic response (Whitsett et al., 1983, 1984a), some entrainment patterns result in a misinterpretation of the photoperiod (Eskes \& Zucker, 1978). Our current studies of entrainment patterns and endocrine changes in young deer mice should clarify the nature of individual variation in pubertal development in this species.

Growth of seminiferous tubules and production of spermatozoa are greater in male deer mice reared in a long photoperiod than in those reared in short days. The various measures of the internal structure and spermatogenic activity of the testis are highly correlated, not only with one another, 
but also with the gross size of the testis. This conclusion conforms to observations for several other species (Amann, 1970). Simple measurement of weight or volume of the testis should be adequate in studies requiring only a general index of testicular maturation; whether the additional cost of histological analysis is warranted will depend on the goals of the given investigation. Histological analysis of testes also supports the view that puberty in males is best regarded as a continuous process (Miller, Whitsett, Vandenbergh \& Colby, 1977; Bediz \& Whitsett, 1979). We can identify no means by which one can unequivocally differentiate discrete states of testicular maturity and immaturity. The size of the testis, tubular development and sperm production all appear to be describable by continuous distributions of values. Smaller testes in the males of this study typically did not lack mature spermatozoa; rather they produced fewer spermatozoa than did larger testes.

Cornified spines are present on the surface of the penis in many species of rodents (Hooper, 1959). In rats and hamsters, at least, the presence of spines in the adult male depends upon exposure to testicular androgen during neonatal life and again in adulthood (Beach \& Levinson, 1950; Whitsett et al., 1980). The spines are very sensitive to androgen and have been used as a bioassay for this hormone when available androgen was too low to stimulate accessory gland growth (Kiernesky \& Gerall, 1973). Exposure of deer mice to 15- and 19-h photoperiods in Exp. 1 stimulated the development of penile spines. The epidermal surface of the penis in these animals was similar to that in adults, except that orientation of the spines toward the body is more pronounced and uniform in adults (J. M. Whitsett, unpublished observation). There was no spine production in most animals exposed to $\leq 11 \mathrm{~h}$ light. Development of a biopsy procedure for repeated sampling would allow measurement of spine density to become a useful index of the reproductive response to photoperiod. Contrary to our expectation, there was little variation in spine length; spines tended to be either absent entirely or present with an apparently mature length and shape. Perhaps this tendency reflects very rapid growth of spines in response to a low level of androgen early in pubertal development.

We thank Jody Khosla for technical assistance and Dr Charles H. Henrikson for histological consultation. This investigation was supported in part by U.S. Environmental Protection Agency Grant CR809428010.

\section{References}

Amann, R.P. (1970) Sperm production rates. In The Testis, pp. 455-470. Eds A. D. Johnson, W. R. Gomes \& N. L. VanDemark. Academic Press, New York.

Beach, F.A. \& Levinson, G. (1950) Effects of androgen on the glans penis and mating behavior of castrated male rats. J. exp. Zool. 114, 159-168.

Bediz, G.M. \& Whitsett, J.M. (1979) Social inhibition of sexual maturation in male prairie deer mice. J. comp. Physiol. Psychol. 93, 493-500.

Clermont, Y. \& Trott, M. (1969) Duration of the cycle of the seminiferous epithelium in the mouse and hamster determined by means of ${ }^{3} \mathrm{H}$-thymidine and radioautography. Fert. Steril. 20, 805 817.

Dark, J., Johnston, P.G., Healy, M. \& Zucker, I. (1983) Latitude of origin influences photoperiodic control of reproduction of deer mice (Peromyscus maniculatus). Biol. Reprod. 28, 213-220.

Desjardins, C. \& Lopez, M.J. (1983) Environmental cues evoke differential responses in pituitary-testicular function in deer mice. Endocrinology 112, 1398-1406.

Elliott, J.A. (1976) Circadian rhythms and photoperiodic time measurement in mammals. Fedn Proc. Fedn Am. Socs exp. Biol. 35, 2339-2346.
Eskes, G.A. \& Zucker, I. (1978) Photoperiodic regulation of the hamster testis: dependence on circadian rhythms. Proc. natn. Acad. Sci. U.S.A. 75, 1034-1038.

Farner, D.S. \& Wilson, A.C. (1957) A quantitative examination of testicular growth in the WhiteCrowned sparrow. Biol. Bull. mar. Biol. Lab. Woods Hole 113, 254-267.

Foster, D.L. (1981) Mechanism for delay of first ovulation in lambs born in the wrong season (fall). Biol. Reprod. 25, 85-92.

Grocock, C.A. (1981) Effect of different photoperiods on testicular weight changes in the vole, Microtus agrestis. J. Reprod. Fert. 62, 25-32.

Hoffmann, J.C. (1973) The influence of photoperiod on reproductive functions in female mammals. In Handbook of Physiology, Section 7, Vol. II, Female Reproductive System, Part 1, pp. 57-77. Ed. R. O. Greep. American Physiological Society, Washington, D.C.

Hoffmann, K. (1981) The role of the pineal gland in the photoperiodic control of seasonal cycles in hamsters. In Biological Clocks in Seasonal Reproductive Cycles, pp. 237-250. Eds B. K. Follett \& D. E. Follett. Wright, Bristol. 
Hooper, E.T. (1959) The glans penis in five genera of cricetid rodents. Occ. Pap. Mus. Zool. Univ. Mich. 613, $1-11$.

Hooper, E.T. (1968) Classification. In Biology of Peromyscus (Rodentia), pp. 27-74. Ed. J. A. King. American Society of Mammalogists.

Imel, K.J. \& Amann, R.P. (1979) Effects of duration of daily illumination on reproductive organs and fertility of the meadow vole (Microtus pennsylvanicus). Lab. Anim. Sci. 29, 182-185.

Johnston, P.G. \& Zucker, I. (1980) Photoperiodic regulation of reproductive development in white-footed mice (Peromyscus leucopus). Biol. Reprod. 22, 983989.

Kiernesky, N.C. \& Gerall, A.A. (1973) Effects of testosterone propionate implants in the brain on the sexual behavior and peripheral tissue of the male rat. Physiol. Behav. 11, 633-640.

Lansman, R.A., Avise, J.C., Aquadro, C.F., Shapira, J.F. \& Daniel, S.W. (1983) Extensive genetic variation in mitochondrial DNA's among geographic populations of the deer mouse Peromyscus maniculatus. Evolution 37, 1-16.

Lawton, A.D. \& Whitsett, J.M. (1979) Inhibition of sexual maturation by a urinary pheromone in male prairie deer mice. Horm. \& Behav. 13, 128-138.

Leblond, C.P. \& Clermont, Y. (1952) Definition of the stages of the cycle of the seminiferous epithelium in the rat. Ann. New York Acad. Sci. 55, 548-573.

Lynch, G.R. \& Gendler, S.L. (1980) Multiple responses to different photoperiods occur in the mouse, Peromyscus leucopus. Oecologia (Berl.) 45, 318-321.

Miller, L.L., Whitsett, J.M., Vandenbergh, J.G. \& Colby, D.R. (1977) Physical and behavioral aspects of sexual maturation in male golden hamsters. J. comp. Physiol. Psychol. 91, 245-259.

Oakberg, E.F. (1956) A description of spermiogenesis in the mouse and its use in analysis of the cycle of the seminiferous epithelium and germ cell renewal. $\mathrm{Am}$. J. Anat. 99, 391-413.

Petterborg, L.J. \& Reiter, R.J. (1980) Effect of photoperiod and melatonin on testicular development in the white-footed mouse, Peromyscus leucopus. J. Reprod. Fert. 60, 209-212.
Pittendrigh, C.S. \& Daan, S. (1976) A functional analysis of circadian pacemakers in nocturnal rodents. I. The stability and lability of spontaneous frequency. $J$. comp. Physiol. 106, 223-252.

Riggs, D.S. (1963) The Mathematical Approach to Physiological Problems. M.I.T. Press, Cambridge, Mass.

SAS Institute Inc. (1982) SAS User's Guide: Statistics, 1982 edn. SAS Institute Inc., Cary, N.C.

Savidge, I.R. (1974) Social factors in dispersal of deermice (Peromyscus maniculatus) from their natal site. Am. Midl. Nat. 91, 395-405.

Sullivan, T.P. (1979) Demography of populations of deer mice in coastal forest and clear-cut (logged) habitats. Can. J. Zool. 57, 1636-1648.

Tahka, K.M., Ruokonen, A., Wallgren, H. \& Teravainen, T. (1983) Temporal changes in testicular histology and steroidogenesis in juvenile bank voles (Clethrionomys glareolus, Schreber) subjected to different photoperiods. Endocrinology 112, 1420-1426.

Whitsett, J.M. \& Lawton, A.D. (1982) Social stimulation of reproductive development in male deer mice housed on a short-day photoperiod. J. comp. Physiol. Psychol. 96, 416-422.

Whitsett, J.M. \& Miller, L.L. (1982) Photoperiod and reproduction in female deer mice. Biol. Reprod. 26, 296-304.

Whitsett, J.M., Ayer, M.L. \& Muse, K.E. (1980) Androgenic control of phallic papillae in hamsters: a quantitative analysis using the scanning electron microscope. Biol. Reprod. 23, 669676.

Whitsett, J.M., Underwood, H. \& Cherry, J. (1983) Photoperiodic stimulation of pubertal development in male deer mice: involvement of the circadian system. Biol. Reprod. 28, 652-656.

Whitsett, J.M., Cherry, J. \& Underwood, H. (1984a) Involvement of the circadian system in photoperiodic control of pubertal development in female deer mice, Peromyscus maniculatus. Experientia 71 (in press).

Whitsett, J.M., Lawton, A.D. \& Miller, L.L. (1984b) Photosensitive stages in pubertal development of male deer mice (Peromyscus maniculatus). J. Reprod. Fert. 72, 269-276.

Received 21 November 1983 